\title{
Greenhouse gas emissions from current and enhanced policies of China until 2030: Can emissions peak before 2030?
}

\author{
Michel den Elzen a,*, Hanna Fekete ${ }^{\mathrm{b}}$, Niklas Höhne ${ }^{\mathrm{b}, \mathrm{c}}$, Annemiek Admiraal ${ }^{\mathrm{a}}$, \\ Nicklas Forsell ${ }^{\mathrm{d}}$, Andries F. Hof ${ }^{\mathrm{a}, \mathrm{e}}$, Jos G.J. Olivier ${ }^{\mathrm{a}}$, Mark Roelfsema ${ }^{\mathrm{a}}$, Heleen van Soest ${ }^{\mathrm{a}}$ \\ a PBL Netherlands Environmental Assessment Agency, P.O. Box 303, 3720 AH Bilthoven, The Netherlands \\ ${ }^{\mathrm{b}}$ NewClimate Institute, Cologne, Germany \\ ${ }^{\mathrm{c}}$ Environmental Systems Analysis Group, Wageningen University, Wageningen, The Netherlands \\ d International Institute for Applied Systems Analysis, A-2361 Laxenburg, Austria \\ e Copernicus Institute of Sustainable Development, Utrecht University, The Netherlands
}

\section{H I G H L I G H T S}

- China has announced its intention to peak $\mathrm{CO}_{2}$ emissions by 2030 or earlier.

- The peak in greenhouse gas emissions would reach 35-40\% above 2010 levels.

- Current policies are likely not to be sufficient to meet the announced 2030 target.

- The expected emission levels reach about 50\% above 2010 levels.

- Our selected enhancement policy measures lead to peaking $\mathrm{CO}_{2}$ emissions before 2030 .

\section{A R T I C L E I N F O}

\section{Article history:}

Received 24 April 2015

Received in revised form

10 September 2015

Accepted 27 November 2015

Available online 7 December 2015

Keywords:

National climate and energy policies

Climate agreement

Renewable targets

\begin{abstract}
A B S T R A C T
In June 2015, China announced its post-2020 reduction targets, its central element being the intention to peak $\mathrm{CO}_{2}$ emissions by 2030 or earlier. China has implemented several policies to reduce its greenhouse gas (GHG) emissions. This study provides emission projections for China up to 2030 given current policies and a selected set of enhanced policies, and compares the results with projected $\mathrm{CO}_{2}$ emission trajectories that are consistent with the announced target for 2030. The projections are based on existing scenarios and energy system and land use model calculations. We project that the $2030 \mathrm{CO}_{2}$ emission level consistent with a peak in $\mathrm{CO}_{2}$ emissions by 2030 ranges from 11.3 to $11.8 \mathrm{GtCO}_{2}$. The corresponding total GHG emission level ranges from 13.5 to $14.0 \mathrm{GtCO}_{2} \mathrm{e}$ in 2030 . Current policies are likely not to be sufficient to achieve the 2030 targets, as our projected total GHG emission level under current policies ranges from 14.7 to $15.4 \mathrm{GtCO}_{2} \mathrm{e}$ by 2030 . However, an illustrative set of enhancement policy measures, all of which are related to national priorities, leads to projected GHG emission levels from 13.1 to 13.7 $\mathrm{GtCO}_{2} \mathrm{e}$ by 2030 - and thus below the levels necessary for peaking $\mathrm{CO}_{2}$ emissions before 2030.
\end{abstract}

(c) 2015 Elsevier Ltd. All rights reserved.

\section{Introduction}

In 2011, at the UN climate summit in Durban, countries agreed to negotiate a new international climate agreement by 2015 , applicable to all countries and to be implemented from 2020 onwards. One of the key elements in the new agreement are the long-term reduction targets beyond 2020, as part of the so-called Intended Nationally Determined Contributions (INDCs). At the UN climate summit in Lima in 2014, it was agreed that countries

\footnotetext{
* Corresponding author.

E-mail address: michel.denelzen@pbl.nl (M.d. Elzen).
}

should submit INDCs well before the Paris climate summit in December 2015.

In November 2014, the US and China already announced greenhouse gas (GHG) emission targets beyond 2020. The US announced a reduction target of 26-28\% below 2005 levels by 2025 , and China announced its intention to achieve the peaking of $\mathrm{CO}_{2}$ emissions around 2030 and to make best efforts to peak early. China further intends to increase the share of non-fossil fuels in primary energy consumption to around 20\% by 2030 (White House, 2014).

On the 30th of June 2015, China submitted an INDC, which in addition to the already announced intentions included the intention to lower the carbon intensity of GDP by $60-65 \%$ below 2005 
levels by 2030, and to increase the forest stock volume by around 4.5 billion cubic metres, compared to 2005 levels. China's INDC also includes a comprehensive list of actions to achieve its 2020 and 2030 targets. A large number of the policies have already been implemented.

National climate policies in China are developing fast (Government of China, 2012; Townshend et al., 2011; Zhou et al., 2010), as can be illustrated by the development of renewable and lowcarbon energy. Since the Medium and Long Term Development Plan (MLTD) for Renewable Energy from 2007, China has increased its renewable energy capacity targets several times. National targets from China's 12th Five-Year-Plan (FYP) and the 12th FYP for Renewable Energy Development include additional renewable capacity targets (The People's Republic of China, 2011, 2012). For example, solar PV targets for 2020 have increased from $1.8 \mathrm{GW}$ in the 2007 MLTD Plan to $50 \mathrm{GW}$ in the 12th FYP and to $100 \mathrm{GW}$ in the recently published Energy Development Strategy Action Plan (2014-2020) (The People's Republic of China, 2014a). Targets for increasing gas production and limiting coal consumption are set in the National Action Plan on Climate Change (2014-2020) and the Energy Development Strategy Action Plan (2014-2020) (The People's Republic of China, 2014a, 2014b).

Literature shows a wide range of energy-related $\mathrm{CO}_{2}$ emission projections for both current and enhanced policies scenarios (Government of China, 2012; IEA, 2013b, 2014; Jiang et al., 2013; Zhang et al., 2014). The main reasons for the wide range are varying GDP growth assumptions, differences in base-year in which the scenario starts, and related to this, differences in assumptions on implementation of current policies. Despite these large differences, all scenarios indicate that if China wants to peak $\mathrm{CO}_{2}$ emissions before 2030 , fast implementation of new policies is needed.

As China is the largest emitter of GHG emissions, being responsible for about 20\% of global GHG emissions, projections of China's GHG emissions and of the effect of its climate policies are of great importance to assess the likelihood of achieving the $2{ }^{\circ} \mathrm{C}$ climate goal. The main objective of this study is to analyse whether current Chinese climate policies and a selected set of enhanced policies could lead to emission trajectories that are consistent with the announced targets for 2030, as described in the INDC.

No recent analyses with global models of the impact of current policies on all GHG emissions up to 2030 exist for China, except for IEA (2014). The studies with global models that do exist are outdated as they do not account for the current policies around renewable energy capacity developments (e.g., Tavoni et al., 2015). The studies with national models as published in the literature (e.g., Chen et al., 2007; Jiang et al., 2013; Johansson et al., 2014; Zhang et al., 2014) also do not fully account for the most recent developments. For this study, we compare our results of the current policies scenario with those of existing national studies (for example, Jiang et al., 2013; Sha et al., 2015), and of the IEA study. It should be noted that as policies in China are subject to change, this paper represents the state of affairs as of April 2015 regarding current policies.

In addition, this study analyses how far China could reduce its emissions with five selected enhanced mitigation measures, all of which are related to current national priorities (for instance, reducing air pollution) and therefore, in the view of the authors, have a high likelihood of being implemented. The selected set of enhanced mitigation measures is illustrative, but all are selected based on a literature review of promising areas for enhanced action, as explained in Section 3.3, taking into account the criteria mitigation potential, co-benefits, and alignment with national priorities. These promising areas include renewable energy, passenger transport, buildings, and forestry.

\section{Methods}

\subsection{Methodology}

The impact of current and enhanced policies on GHG emissions was estimated by two different methods:

(i) Bottom-up framework: calculations based on existing scenarios from IEA and US EPA, complemented with own calculations of the impact of individual policies in various subsectors. The framework was developed for, and published in Fekete et al. (2013b) and is also used in the climate action tracker. ${ }^{1}$ The GHG projections for China are based on the energy-related $\mathrm{CO}_{2}$ emission projections of the current policies scenario of the IEA's World Energy Outlook 2014 (WEO2014) (IEA, 2014) and the US EPA non- $\mathrm{CO}_{2}$ emission projections up to 2030 (US EPA, 2012). For projections of non-energy-related $\mathrm{CO}_{2}$ emissions, the growth rates from the IEA's Energy Technology Perspectives 2010 were applied. We adapted these scenarios to include the latest policies that are adopted by China. For example, we adapted the coal use, so that the recently agreed cap on coal consumption is met. To compensate for the reduced coal use we either assumed more energy efficiency or an increase in energy supply from other fuels.

(ii) FAIR/TIMER model: calculations based on the FAIR policy model (den Elzen et al., 2014) and the TIMER energy model (Van Vuuren et al., 2014). The starting point for the FAIR/ TIMER model calculations is an updated version of the OECD (2012) business-as-usual emission scenario (TIMER baseline). The policy targets (such as renewable capacity targets) were implemented in the TIMER energy supply and demand submodels, resulting in a deviation from the business-as-usual emissions pathway. After the target year, until 2030, the TIMER model calculates market shares of energy technologies by a multinomial logit function, so that technologies with lower costs gain larger market shares. Climate policies that encompass end-of-pipe measures, such as HFC reduction schemes, are implemented in the FAIR model by setting a tax level in accordance with the target reduction. The accounting method for total primary energy supply in our calculations is based on the standard Chinese method, which is also used in the national plans, and excludes traditional biomass fuels. We use a time-dependent conversion efficiency, which improves in time, for nuclear, hydro and other non-biomass renewables to calculate the equivalent level in terms of electricity generated by fossil-fuelled power plants, excluding heat generation.

Both methods were supplemented with land use, land-use change and forestry (LULUCF) $\mathrm{CO}_{2}$ emission projections based on land-use and agricultural policies using IIASA's global land-use model GLOBIOM (Havlík et al., 2014) and global forest model G4M (Gusti, 2010). National afforestation and deforestation rates in the models are calibrated to historical data (FAO STAT) using a calibration procedure to produce historically consistent reference levels (Gusti and Kindermann, 2011). From 2010 onwards, the trend in land-use emissions is fully based on model estimates taking into account socio-economic development and its related impacts on food, feed, and fibre demand.

Population, GDP and bioenergy demand projections were taken from the WEO2014 (IEA, 2014) to harmonize estimates across models. In addition, to account for the uncertainties, we also analysed an alternative projection for LULUCF $\mathrm{CO}_{2}$ emissions, for which it was assumed that emission sinks will become slightly

\footnotetext{
1 www.climateactiontracker.org.
} 
smaller (by $20 \%$ relative to 2005 ) and that emissions from forest and grassland conversion will remain constant. Section 3 provides more detail about the methodology used for the assessment of specific policies.

\subsection{Historical emissions}

Official Chinese data is only available for two inventory years $(1994,2005)$ from two national communications (Government of China, 1994, 2012), which differ in scope. For historical emissions until 2010 we therefore use a combination of international data sources for energy-related $\mathrm{CO}_{2}$ emissions (IEA, 2013a) and nonenergy-related $\mathrm{CO}_{2}$ emissions and other GHG emissions (EDGAR 4.2 FT2010) (JRC/PBL, 2012), and $\mathrm{CO}_{2}$ emissions and removals from activities relating to land use, land-use change and forestry (LULUCF) from FAOSTAT data (http://faostat3.fao.org/faostatgateway).

\subsection{Uncertainties}

All numbers in the following sections involve uncertainties. The most important uncertainties in emission projections relate to uncertainty in historical emissions and GDP growth projections.

Emission projections start from a base year based on historical data. As different historical data sources show emission levels that vary by up to $2 \mathrm{GtCO}_{2}$ in 2010 (Guan et al., 2012), the choice for a certain historical emission dataset affects future emission projections. Guan et al. (2012) compiled the $\mathrm{CO}_{2}$ emission inventories for China's 30 provinces for the period 1997-2010, and found that total $\mathrm{CO}_{2}$ emissions for 2010 differ by $1.4 \mathrm{GtCO}_{2}$ compared to the $\mathrm{CO}_{2}$ emissions calculated on the basis of the two publicly available official energy data sets. Zhu (2014) reviewed the $\mathrm{CO}_{2}$ emissions data for China provided by various international organisations and databases and compared those with China's data for 2005 from the second national commnunication (Government of China, 2012) and own estimates for 2006-2011 using the same implied emission factors for primary fossil fuels and cement clinker production as for 2005. Zhu concluded that IEA (2013a) has the best comparability with China's official data for 2005 and the subsequent trend.

Fig. 1 shows the most recent historical $\mathrm{CO}_{2}$ emission trends from several databases.

The differences in historical energy-related $\mathrm{CO}_{2}$ emissions between datasets can be explained by (a) differences in data sources for statistics of fuel consumption, both in physical units (e.g. ton of coal) and the net calorific value (e.g. GJ/metric ton), and in release years of these datasets; and (b) differences in emission factors used (e.g. $\mathrm{kg} \mathrm{CO} / \mathrm{GJ}$ fuel). For example, CDIAC uses the United Nations Statistical Office data (statistical publications of each country) and IEA and EDGAR use IEA data (IEA, 2013a) for fuel statistics, on which their emission calculations are based. The EDGAR dataset uses different releases of IEA energy statistics than the IEA, which always uses the latest release. In addition, datasets may differ in the level of disaggregation of fuel types used for the emissions calculation, e.g. for hard coal and oil products several subtypes may be distinguished with specific emission factors (Andres et al., 2012). IEA and EDGAR use more detailed calculation than CDIAC that uses one factor for hard coal and one for all oil products. Finally, datasets are based on different methodologies to estimate country emissions from non-energy use of fossil fuels, use as reductant in blast furnaces for iron making, and use as chemical feedstock. More details are provided in Olivier et al. (2014). The IEA data are closest to the official national $\mathrm{CO}_{2}$ emissions, while CDIAC data differ from 7\% in 2005 to $16 \%$ in 2011 (Fig. 1). For the relatively small source of $\mathrm{CO}_{2}$ emissions from limestone use in cement production, CDIAC uses a global emission factor per ton of cement produced, whereas the EDGAR datasets correct for the fraction of clinker in cement, when different from the default fraction assumed. Therefore, the EDGAR data is closer to official Chinese $\mathrm{CO}_{2}$ emissions for cement production than CDIAC, the latter differing from 30\% in 2005 to 55\% in 2011 with official data.

Most industrialised countries estimate the uncertainty in their official total $\mathrm{CO}_{2}$ emissions at 2-5\% (95\% confidence interval) and differences between IEA and EDGAR datasets and these official reported $\mathrm{CO}_{2}$ emissions are mostly also in this range - with a few exceptions (Olivier et al., 2014). For China, it is estimated that most international datasets have an uncertainty of the order of $10 \%$ (Andres et al., 2012; Olivier et al., 2014), but some estimated the uncertainty in the late 2000s as high as 15-20\% (Gregg et al., 2008).

Despite this uncertainty, recent updates show that emissions in China have increased faster than previously expected, and reached around $11.1 \mathrm{GtCO}_{2} \mathrm{e}$ in 2010 excluding LULUCF (JRC/PBL, 2012). The LULUCF $\mathrm{CO}_{2}$ emissions were estimated at around $-0.3 \mathrm{GtCO}_{2} \mathrm{e}$ in 2010 (FAOSTAT). In 2012 and 2013 the growth in $\mathrm{CO}_{2}$ emissions in China has slowed down, partly due to a lower GDP growth (about $7.5 \%$ instead of the decadal average of around $10 \%$ ), and, related to this, to a lower growth rate in cement, steel and electricity production (almost half of the growth rates in most of the previous

\section{(a) $\mathrm{CO}_{2}$ emission from fossil fuel use for China}

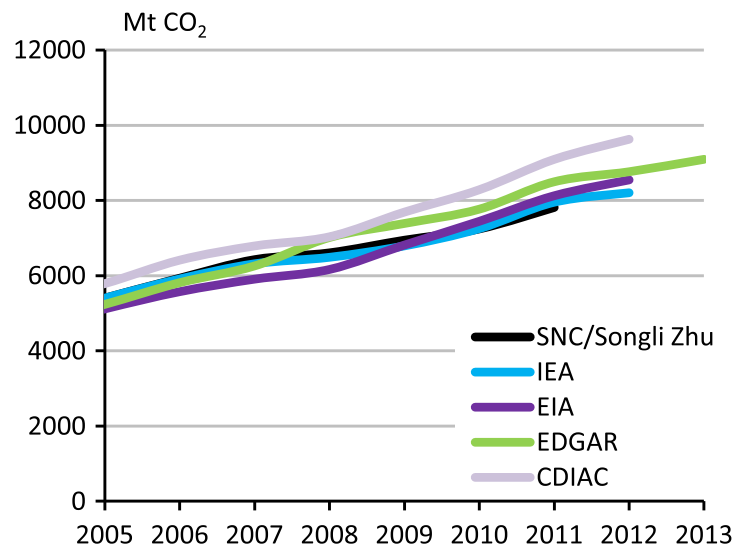

\section{(b) $\mathrm{CO}_{2}$ emissions from cement production}

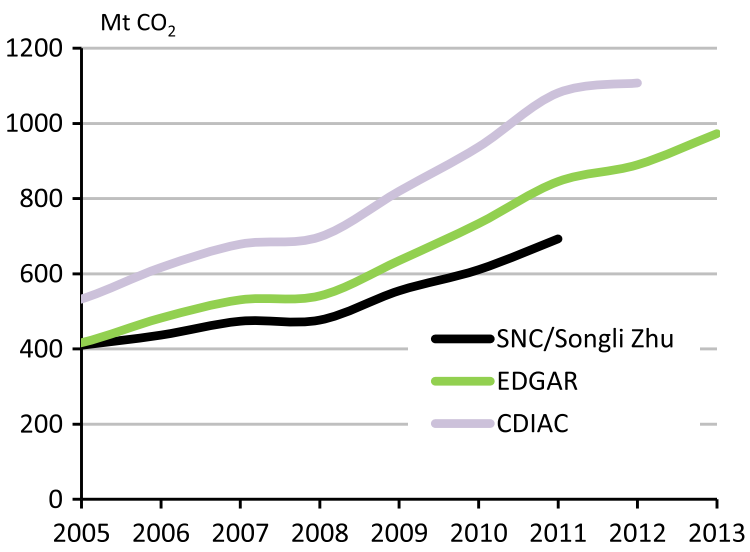

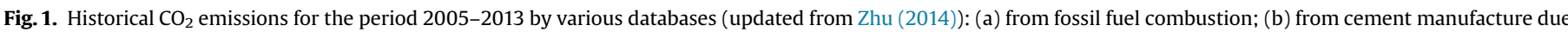

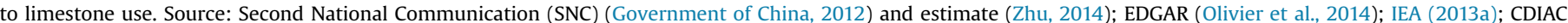
(Boden et al., 2013); EIA (2015). 
years (Olivier et al., 2014)). In 2014, China's coal consumption fell by $2.9 \%$ according to official preliminary Chinese energy statistics for 2014 (NBSC, 2015) (in May this was updated to 0.9\%), crude oil consumption increased by $5.9 \%$, natural gas consumption increased by $8.6 \%$, and cement production increased by $2.3 \%$. These changes, combined with an increase in electricity production from renewable sources of $15.7 \%$, results in a projected increase of China's $\mathrm{CO}_{2}$ emissions in 2014 of around $0.9 \%$.

The estimates mentioned above do not include a downward revision of $\mathrm{CO}_{2}$ emissions suggested in a recent paper by Liu et al. (2015), nor an upward revision recently announced by NBCS (2015). However, the downward revision for EDGAR would be about $6 \%$ in 2013 , and not $14 \%$ as suggested by Liu et al., since the energy statistics used by IEA and EDGAR already take account of much of the concern of the paper on the total coal consumption. Since the upward revision of coal statistics announced by NBSC is of a similar level but of opposite sign, the total impact of both corrections will probably be rather small and definitively within the $10 \%$ uncertainty range estimated for China. More details of our assessment of the paper of Liu et al. (2015) can be found in Olivier et al. (2015).

Finally, the effect of $\mathrm{CO}_{2}$ intensity targets and various policy targets depends on future GDP growth, which is uncertain. Growth rates over the last 10 years have been higher than expected; however, recently, growth has slowed down. It is unclear how GDP growth will develop up to 2020. The Second National Communication (Government of China, 2012) assumes an annual GDP growth of 7\% between 2010 and 2020, and the WEO2014 assumes an annual growth of $6.9 \%$ for the period $2012-2020$, and $5.3 \%$ for 2020-2030.

\section{Results}

The following sections describe in detail China's 2020 pledge and current policies, our analysis of the impact of those, and an assessment of enhanced policies.

\subsection{China's 2020 Pledge made in the Cancún Agreements}

China's pledge consists of reducing its $\mathrm{CO}_{2}$ emission intensity (emissions per unit of GDP) by 40-45\% by 2020, compared to 2005 levels, increasing the share of non-fossil energy in primary energy supply to $15 \%$ by 2020 (including nuclear energy), and increasing the forest coverage by 40 million hectares and forest stock volume by 1.3 billion $\mathrm{m}^{3}$ by 2020, relative to 2005 levels (UNFCCC, 2011).

We estimate the GHG emissions in 2020 that would be consistent with this pledge (Table 1). The second national communication (Government of China, 2012) presents an "enhanced policy" scenario, that accounts for the impact of the pledge of $45 \%$ reduction in $\mathrm{CO}_{2}$ emission intensity. Under the enhanced policy scenario, which includes policies and targets implemented and planned in the 12th and 13th Five Year Plan (up to 2020), emissions reach $9.9 \mathrm{GtCO}_{2}$. As these emissions only include energyrelated $\mathrm{CO}_{2}$ emissions, we added industry-related $\mathrm{CO}_{2}$, LULUCF $\mathrm{CO}_{2}$ and non- $\mathrm{CO}_{2} \mathrm{GHG}$ emissions. For the industry-related $\mathrm{CO}_{2}$ emissions, a similar trend to that of the energy-related $\mathrm{CO}_{2}$ emissions is used, using the EDGAR estimate in 2012 as starting point. For the non- $\mathrm{CO}_{2}$ GHG emissions, the reference scenario of the EPA (US EPA, 2012) is used. This results in a GHG emission level (including LULUCF) of $13.2 \mathrm{GtCO}_{2} \mathrm{eq}$ in 2020. For a $40 \%$ reduction in $\mathrm{CO}_{2}$ emission intensity, energy-related $\mathrm{CO}_{2}$ emissions would be about $10.7 \mathrm{GtCO}_{2} \mathrm{e}$ in 2020 , and the GHG emission level (including LULUCF) would be $14.3 \mathrm{GtCO}_{2} \mathrm{eq}$ (Table 1 ). The effect of $\mathrm{CO}_{2}$ intensity targets depends on future GDP growth. A $1 \%$ lower growth rate would decrease the targeted emission level of the $\mathrm{CO}_{2}$ intensity
Table 1

The energy-related $\mathrm{CO}_{2}$ emissions and all greenhouse gas emissions (including LULUCF) by 2020 that meet China's pledge (intensity targets and non-fossil energy target), for various studies $\left(\mathrm{GtCO}_{2}\right)$.

\begin{tabular}{|c|c|c|}
\hline Scenario & $\begin{array}{l}\text { Energy-related } \\
\mathrm{CO}_{2} \text { emissions }\end{array}$ & $\begin{array}{l}\text { All greenhouse gas } \\
\text { emissions (including } \\
\text { LULUCF) }\end{array}$ \\
\hline \multicolumn{3}{|l|}{$\begin{array}{l}\text { Based on the Second National } \\
\text { Communication }\end{array}$} \\
\hline $\begin{array}{l}40 \% \text { reduction in } \mathrm{CO}_{2} \text { emission } \\
\text { intensity }\end{array}$ & 10.7 & 14.3 \\
\hline $\begin{array}{l}45 \% \text { reduction in } \mathrm{CO}_{2} \text { emission } \\
\text { intensity }\end{array}$ & 9.9 & 13.2 \\
\hline $\begin{array}{l}\text { Projections of GDP growth of } 8 \% / \\
\text { year for the period } 2010-2020\end{array}$ & $11.3[10.8 ; 11.8]$ & $14.8[14.4 ; 15.3]$ \\
\hline $\begin{array}{l}\text { Projections of GDP growth of } 6 \% / \\
\text { year for the period } 2010-2020\end{array}$ & $9.4[9.0 ; 9.8]$ & $12.9[12.5 ; 13.3]$ \\
\hline UNEP Gap 2014 report & N.A. ${ }^{a}$ & $14.513 .6[13.0 ; 13.8]^{\mathrm{b}}$ \\
\hline \multicolumn{3}{|l|}{ Based on official estimate } \\
\hline Based on model studies & & \\
\hline
\end{tabular}

a N.A.: Not available.

b 20 th to 80th percentile range of the included model studies.

target by about $1 \mathrm{GtCO}_{2} \mathrm{e}$ (den Elzen et al., 2013).

For comparison, UNEP (2014) estimated a GHG emission level of 13.0-13.8 $\mathrm{GtCO}_{2} \mathrm{e}$ including LULUCF, with a central estimate of 13.6 $\mathrm{GtCO}_{2} \mathrm{e}$ based on seven model studies. It also presents an official estimate of $14.5 \mathrm{GtCO}_{2}$ eq, based on a $40-45 \%$ improvement in $\mathrm{CO}_{2}$ intensity and an average annual economic growth of $7 \%$, consistent with official projections from the Second National Communication.

\subsection{Current policies}

\subsubsection{Description of policies}

Our assessment includes the most recent economy-wide climate and energy policies for the period 2011-2015 (Table 2), as established in the 12th FYP and the 12th FYP for Renewable Energy Development (The People's Republic of China, 2011, 2012), as well as targets for gas and limiting coal consumption set in the National Action Plan on Climate Change (2014-2020) and the Energy Development Strategy Action Plan (2014-2020) (The People's Republic of China, 2014a, 2014b).

3.2.1.1. 12th Five-Year-Plan. The 12th Five-Year-Plan was published in March 2011, and includes translations of the voluntary international commitments (pledges) into domestic policies (China National Energy Administration China National Renewable EC, 2012). It contains the following climate and energy targets: (i) a $\mathbf{C O}_{2}$ intensity target aimed at a $17 \%$ decrease in carbon dioxide emissions per unit of GDP, between 2011 and 2015; (ii) A nonfossil energy target aimed at increasing the share of non-fossil fuels (including nuclear) in primary energy consumption from $8.3 \%$ in 2010 to $11.4 \%$ by 2015; (iii) An energy-intensity target aimed at a $16 \%$ decrease in primary energy consumption per unit of GDP, between 2011 and 2015. As to the land-use sector, the 12th Five-Year-Plan targets to afforest an additional 12.5 million ha of land and increase the forest stock by an additional 0.6 billion $\mathrm{m}^{3}$, relative to 2005 levels by 2015 . This continues the trend of the previous 11th Five-Year-Plan, where support was directed to afforestation projects and enhancements of sustainable forest management, which reportedly led to the afforestation of 24.67 million ha of land (Government of China, 2012). These targets are supported by numerous supportive policies, such as the Top 10,000 Energy Consuming Enterprises programme, ${ }^{2}$ financial incentives for renewable energy, and efficiency labelling and standards. 
Table 2

Overview of the current policies analysed for China.

\begin{tabular}{|c|c|c|}
\hline Sector & Policy/measure & Target \\
\hline Economy/state wide & $\begin{array}{l}\text { Implementation of measures in the } 12 \text { th Five-Year } \\
\text { Plan (FYP) }\end{array}$ & $\begin{array}{l}\text { - A } 17 \% \text { cut in } \mathrm{CO}_{2} \text { intensity by } 2015 \text { and a } 16 \% \text { reduction in energy intensity by 2015, com- } \\
\text { pared with } 2010 \text { levels }\end{array}$ \\
\hline \multirow[t]{8}{*}{ Energy supply } & Medium and Long Term Development Plan for & - Increasing the share of gas in total primary energy supply to $10 \%$ by 2020 \\
\hline & Renewable Energy & $\begin{array}{l}\text { - Limiting coal consumption to a maximum of } 4.2 \text { billion tonnes from } 2020 \text { onwards (coal } \\
\text { cap) }\end{array}$ \\
\hline & & - 11.4\% share of non-fossil fuels (including nuclear) in primary energy consumption by 2015 \\
\hline & $\begin{array}{l}\text { Updates for renewable energy capacity in } 12 \text { th } \\
\text { FYP }\end{array}$ & $\begin{array}{l}\text { - } 700 \mathrm{GW} \text { renewable electricity by } 2020 \text { ( } 420 \mathrm{GW} \text { hydropower, } 200 \mathrm{GW} \text { wind, } 50 \mathrm{GW} \text { solar, } \\
30 \mathrm{GW} \text { biomass, } 0.1 \mathrm{GW} \text { tidal by } 2020 \text { ) }\end{array}$ \\
\hline & - Renewable electricity & - 800 million $\mathrm{m}^{2}$ collector area \\
\hline & - Solar hot water & - 10 million tonnes ethanol, 2 million tonnes biodiesel \\
\hline & - Biofuel & - 58 GW nuclear energy by 2020 and 150 GW by 2030 \\
\hline & - Nuclear energy & \\
\hline \multirow[t]{2}{*}{ Transport } & $\begin{array}{l}\text { - Subsidies for hybrid and electric vehicles, biofuel } \\
\text { target }\end{array}$ & - Ethanol blending mandates $10 \%$ in selected provinces \\
\hline & - Fuel efficiency standard & $-5 \mathrm{l} / 100 \mathrm{~km}$ for new cars $(20 \mathrm{~km} / \mathrm{l})$ by 2020 \\
\hline Industry & $\begin{array}{l}\text { Energy efficiency: Top 10,000 energy-consuming } \\
\text { enterprises programme }\end{array}$ & $\begin{array}{l}\text { Energy saving targets for energy-intensive industries, to be achieved by } 2015 \text {. The target for } \\
\text { steel producers is } 25 \% \text {, for the non-ferrous metal industry } 18 \% \text {, and for cement production } 3 \%\end{array}$ \\
\hline Forestry & $\begin{array}{l}\text { Promotion of afforestation and sustainable forest } \\
\text { management }\end{array}$ & $\begin{array}{l}\text { Increasing the forest area by } 40 \text { million hectares and the forest stock volume by } 1.3 \text { billion } \mathrm{m}^{3} \text {. } \\
\text { This is to be achieved by } 2020 \text {, relative to } 2005 \text { values. }\end{array}$ \\
\hline
\end{tabular}

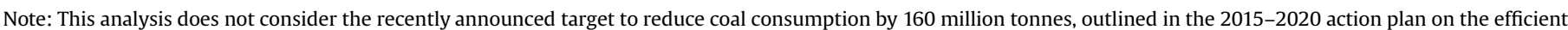
use of coal.

3.2.1.2. 12th Five-Year Plan for renewable energy development. The targets for additional renewable capacities were increased more than twofold for some technologies in the 12th Five-Year Plan for renewable energy development (The People's Republic of China, 2012), compared to the previous version from 2007. The installed renewable energy capacity target for 2020 is $420 \mathrm{GW}$ of hydropower, $200 \mathrm{GW}$ of wind power, $50 \mathrm{GW}$ of solar power and $30 \mathrm{GW}$ of biomass power (total target of $700 \mathrm{GW}$ ). In the bottom-up method, this 2020 target is assumed to grow to $1400 \mathrm{GW}$ renewable energy capacity by 2030 for the current policies scenario based on Bloomberg New Energy Finance (2013). The TIMER model projects renewable capacities based on the multinomial logit function (see Section 2.1), including the learning effect induced by additional installed renewable technologies compared to the business-as-usual scenario, leading to $1050 \mathrm{GW}$ renewable energy capacity by 2030. Our renewable capacity targets are somewhat higher than the $850 \mathrm{GW}$ as assumed in the current policies scenario of IEA (2014) and the $1005 \mathrm{GW}$ by 2030 of the IRENA (2014).

3.2.1.3. Medium and Long Term Development Plan for Renewable Energy. The Medium and Long Term Development Plan for Renewable Energy contains targets for increasing solar thermal water heating ( 800 million $\mathrm{m}^{2}$ area of solar thermal collectors by 2020) and replacing petroleum-based fuel with biofuels (10 million tonnes ethanol, 2 million tonnes biodiesel by 2020). The plan also contains targets for biogas and geothermal heat, although these are of a smaller order of magnitude (National Development Reform Commission, 2007).

3.2.1.4. Energy Development Strategy Action Plan. Finally, we analysed the targets for gas and for limiting coal consumption as set in the Energy Development Strategy Action Plan (2014-2020). These targets include (i) a fossil fuel target aimed at increasing the share of gas in total primary energy supply to $10 \%$ by 2020 , and (ii) limiting coal consumption to a maximum of 4.2 billion tonnes from 2020 onwards (coal cap).

\footnotetext{
${ }^{2}$ http://iepd.iipnetwork.org/policy/top-10000-energy-consuming-enterprises-
} program.
3.2.1.5. Other policies. The Air Pollution Control Action Plan (Government of China, 2013) further bans construction of coal-fired power plants in various regions. While this helps to reduce local air pollution, the overall effect on emissions is unclear, as the same capacities could be moved to other geographic regions. We therefore assumed no impact on GHG emissions. A pilot ETS scheme at the national level is being planned and, according to most recent information, will start in 2020 (Chen and Reklev, 2014). For this analysis we did not include the impact of ETS in the calculations, as the final design and implementation of the ETS is under development.

Nuclear. In 2012 the State Council published a White Paper on energy policy. At the same time it announced that China's nuclear programme, suspended after the Fukushima disaster, would resume but at a slower pace than initially planned (Nachmany et al., 2014). The current plans include a three-fold increase in nuclear capacity from current (2015) levels, to at least 58 GW by 2020-21, then some $150 \mathrm{GW}$ by $2030 .^{3}$ This nuclear capacity projection is assumed in our calculations. However the post-Fukushima slowdown may mean that the 2030 figure is only about $120 \mathrm{GW}$, which is assumed in the current policies scenario from the IEA (2014) and reference scenario in the IRENA (2014).

Transport. Chinese Automotive Fuel Economy Policy. ${ }^{4}$ In 2012, China's State Council released the Energy-Saving and New Energy Vehicle Industrialization Plan, ${ }^{5}$ which contains a fuel efficiency standard starting in 2015 (already in place), and a standard of $5 \mathrm{l} /$ $100 \mathrm{~km}$ by 2020 (Braun et al., 2014). Furthermore, subsidies exist for hybrid and electric vehicles.

\subsubsection{Assessment of current policies}

The $\mathrm{CO}_{2}$-intensity, energy-intensity, and non-fossil-fuel energy targets have been analysed for the year 2015 using both FAIR/ TIMER model calculations and CAT analysis. The $\mathrm{CO}_{2}$ intensity and energy intensity targets for 2015 are achieved in the TIMER current policy scenario. As the policies from the 12th FYP are already included in the current policies scenario of IEA's WEO2014, these

\footnotetext{
${ }^{3}$ http://www.world-nuclear.org/info/Country-Profiles/Countries-A-F/ChinaNuclear-Power/.

4 www.unep.org/transport/gfei/autotool/case_studies/apacific/china/CHINA\% 20CASE\%20STUDY.pdf.

5 www.gov.cn/zwgk/2012-07/09/content_2179032.htm.
} 


\section{Impact of climate policies on greenhouse gas emissions for China}

Including $\mathrm{CO}_{2}$ emissions from land use

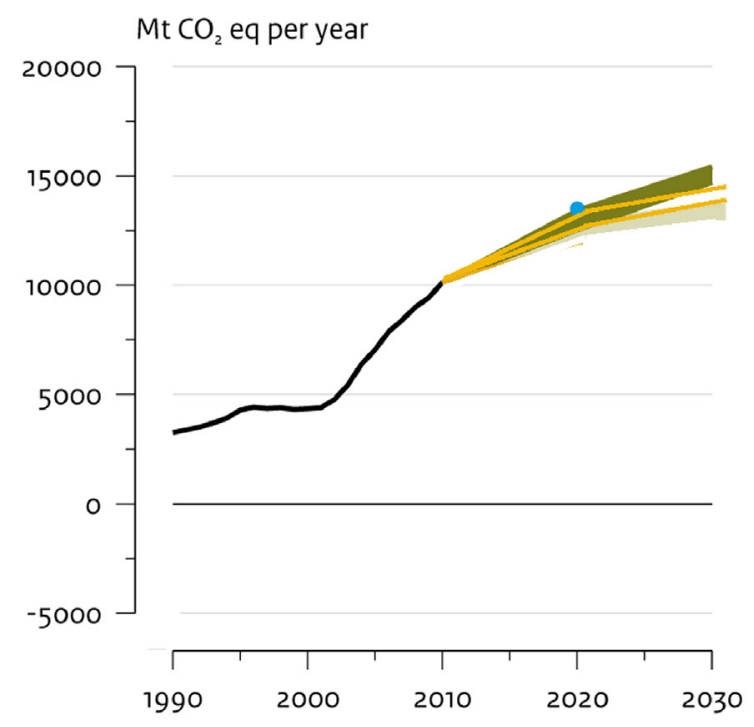

- History
$\mathrm{CO}_{2}$ emissions from land use

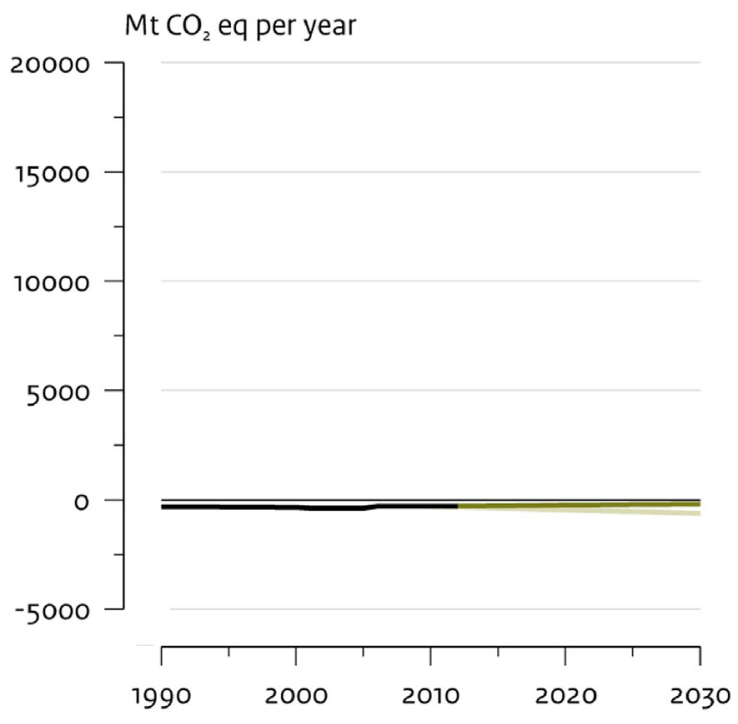

- Pledge

Enhanced policies (bottom-up) INDC

\section{Source: PBL FAIR/TIMER model; Ecofys \& NewClimate Institute calculations; IIASA GLOBIOM/G4M model}

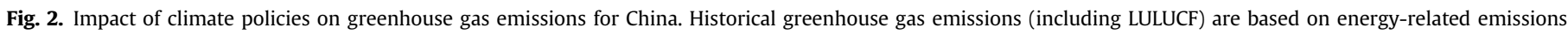

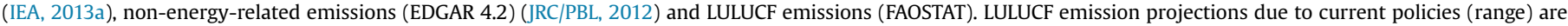
based on FAOSTAT and model calculations. The LULUCF emission projections for enhanced policies are based on IIASA model calculations.

targets do not lead to any further reductions according to the CAT analysis.

The renewable energy capacity targets results in an emission reduction of $1165 \mathrm{MtCO}_{2}$ in the TIMER current policies scenario with respect to a no climate policy baseline, whereas in the CAT analysis the reduction is limited due to the assumed capacity targets in the IEA current policies scenario.

The effect of limiting coal consumption to 4.2 billion tonnes was estimated by first converting the target into about 2200 Mtoe (million tonnes of oil equivalent), based on the assumption of an average heating value of coal in China of $22.4 \mathrm{MJ} / \mathrm{kg}$ coal (Sun, 2010) and a world average of $30.1 \mathrm{MJ} / \mathrm{kg}$ coal. ${ }^{6}$ According to the WEO2014 (IEA, 2014), coal consumption in 2012 was 1977 Mtoe. In order to limit coal consumption to 2200 Mtoe, a maximum increase in consumption of $11 \%$ is allowed between 2012 and 2020 , and we assumed a stabilisation of coal consumption thereafter. Under FAIR/TIMER current policies scenario, historical coal consumption trend before 2012 was similar to the WEO2014 trend. The increase from 2012 towards 2020 is about $10 \%$ in the TIMER projection, which is below the growth rate that corresponds with the cap of 2200 Mtoe. Coal consumption is projected to stabilise thereafter. In the FAIR/TIMER calculations, this peaking of coal consumption is due to the renewable energy policies as stated in the 12th Five-Year-Plan; therefore, no additional policy is required to reach the coal cap. The same holds for the gas share target of $10 \%$ for 2020. In the CAT calculations, the cap on coal will also have a limited impact in 2020. However, with the assumption that coal

\footnotetext{
${ }^{6}$ http://www.engineeringtoolbox.com/coal-heating-values-d_1675.html.
}

consumption will not increase further thereafter, the cap limits emissions in the period up to 2030 and thus will have an impact in that period. The assumption that the use of coal will not increase after 2020 is based on recent developments of actual decreasing coal consumption in China and on discussions about peaking coal as a prerequisite to peak emissions by 2030 at the latest.

Summarising, under current national policies China's emissions are projected to lead to approximately the same emission levels as those required to achieve the pledge by 2020 , as illustrated in Fig. 2. The largest impact is expected from the renewable energy capacity targets defined in the 12th FYP for Renewable Energy Development (responsible for about $60 \%$ of emission reductions with respect to a no climate policy baseline). The absolute emission level resulting from the pledge strongly depends on economic growth, which is very uncertain. Many studies have also indicated that China will meet its 2020 carbon intensity target commitment (Cansino et al., 2015; Jiang et al., 2013; Zhang et al., 2014), except for the trend analysis of Yang et al. (2014).

Under current policies, China is projected to emit 12.5-13.4 $\mathrm{GtCO}_{2} \mathrm{e}$ by 2020 and $14.7-15.4 \mathrm{GtCO}_{2}$ e by 2030 (including emissions from LULUCF) (see Table 3), which is about $46-53 \%$ above the 2010 level. Fig. 3 shows the projections of the per capita GHG emissions, the total $\mathrm{CO}_{2}$ emissions, and per unit of GDP, as well as the renewable energy share of total primary energy supply (TPES) and (d) share of renewable and nuclear (non-fossil) of TPES. The cited Figures and Tables also show the projections for the enhanced policies scenario, and the emission levels consistent with China's INDC, as explained in the following sections. 
Table 3

Greenhouse gas emissions in China for the FAIR/TIMER calculations and bottom-up analysis, according to various policy scenarios, including LULUCF emissions, in 2005 and 2010 and by 2020 and $2030\left(\mathrm{GtCO}_{2} \mathrm{e}\right)$. Numbers in brackets represent emissions relative to 2010 levels.

\begin{tabular}{|c|c|c|c|c|}
\hline Scenario & 2005 & 2010 & 2020 & 2030 \\
\hline Pledge & & & $13.5(33 \%)$ & \\
\hline Current policies & 7.0 & 10.1 & $\begin{array}{l}{[12.5 ; 13.4] \text { ([24\%; }} \\
33 \%])\end{array}$ & $\begin{array}{l}{[14.7 ; 15.4] \text { ([46\%; }} \\
53 \%])\end{array}$ \\
\hline Enhanced policies & & & $\begin{array}{l}{[12.1 ; 12.9] \text { ([20\%; }} \\
28 \%])\end{array}$ & $\begin{array}{l}{[13.0 ; 13.7] \text { ([30\%; }} \\
35 \%])\end{array}$ \\
\hline INDC & & & $\begin{array}{l}{[12.5 ; 13.4] \text { ([24\%; }} \\
33 \%])\end{array}$ & $\begin{array}{l}{[13.5 ; 14.0]([35 \% ;} \\
40 \%])\end{array}$ \\
\hline
\end{tabular}

3.2.2.1. Comparison with national and global studies. For this study, we compare our results of the current policies scenario with the original or updated emission projections from the national studies if available (for example, Jiang et al., 2013; Sha et al., 2015), and with the IEA study. For the comparison, we focus on the energyrelated $\mathrm{CO}_{2}$ emissions, as these are given in the national studies and IEA. Our study shows an increase from about $8 \mathrm{GtCO}_{2}$ in 2010 to $11-11.5 \mathrm{GtCO}_{2}$ in 2030. Jiang et al. (2013) shows a similar increase to about $11.6 \mathrm{GtCO}_{2}$ in 2030 for the business-as-usual scenario. The continued effort scenario in Zhang et al. (2014) shows an increase towards $12 \mathrm{GtCO}_{2}$ in 2030. A similar projection is found for the current policies scenario of the IEA. Concluding, our study gives somewhat lower energy-related $\mathrm{CO}_{2}$ emissions projections, mainly as the most recent updates in the renewable energy capacity developments are included here, but not in the national and IEA studies.

\subsection{The enhanced policies scenario}

\subsubsection{Policy selection}

This section presents the analysis of five selected promising enhanced mitigation policies, given the relevance and opportunities in the national context. The enhanced policy measures were selected based on a literature review of promising areas for enhanced action, taking into account the criteria mitigation potential, co-benefits, and alignment with national priorities. We assumed that policies that have significant co-benefits and that are in line with national priorities have a higher likelihood of being implemented.

The main sources for the literature review were World Bank and ClimateWorks Foundation (2014), Ecofys and Wuppertal Institute, IEA (2013b); Fekete et al. (2013b); World Bank, 2007; Richerzhagen et al. (2008); Government of China (2013); ICCT (2014); Braun et al. (2014), and Grantham Institute for Climate Change (2010).

The policies were selected to be attractive to the country as they are mostly directed at reducing local air pollution and other co-benefits, and at the same time achieve highest possible GHG emission reductions (see Table 4) (e.g., European Environmental Agency, 2014; World Bank and Climate Works Foundation, 2014). For example, the co-benefits of building efficiency, i.e. enhancements in current building standards, consist of energy saving and increasing comfort levels for end users, and reducing pollutant emissions from direct fuel combustion in cities.

In a technical report (Fekete et al., 2015), we have explored more reduction measures, i.e. methane reduction from fossil fuel production, energy efficiency of industrial processes, efficiency of appliances, and more promotion of electric vehicles. As the impact of these additional measures in reducing GHG emissions is much lower, we have decided not to present these here but focused on a few major policies only. One additional measure that is not presented in this paper but which can have a significant impact is promotion of energy efficiency of industrial processes, which could lead to a reduction of $600 \mathrm{MtCO}_{2} \mathrm{e}$ by 2030 (Fekete et al., 2015).

Table 5 presents the selected enhanced policy measures based on the possible areas of enhanced action given in Table 4. These enhanced policy measures are either additional to the policies in the current policies scenario, or show an enhanced ambition of current policies, as described in Table 5. Policies that have increased ambitions in this scenario compared to the current policies scenario are the increased renewable energy target and the increased efficiency improvements in transport.

It should be noted that the selected enhanced mitigation measures do not give a recipe for China on how to implement ambitious climate policies. It merely shows the possibilities of some chosen standard measures that are successfully implemented in other countries. Actual implementation should consider local circumstances and criteria that go further than mere emission reduction. Based on these considerations, other measures might be more appropriate.

\subsubsection{Energy supply; renewable energy target}

For the enhanced policy scenario we analysed the effect of an increase in the share of renewable electricity of 1.35 percentage points per year (using IEA primary energy accounting), based on the average increase over the last decade of Germany and the United Kingdom - countries with successful renewable energy policy frameworks. This implies reaching a share of around $44 \%$ renewable energy in electricity supply (excluding nuclear energy) by 2030 (in 2012, the share was 20.1\%). The additional generation from renewable energy replaces coal-fired generation first, followed by oil and gas. This policy, in combination with the coal consumption cap in the current policies scenario, leads to a situation where no new coal-fired power plants are being built after 2020. Emission reductions beyond the current policies scenario are expected to be $395-500 \mathrm{MtCO}_{2} \mathrm{e}$ by 2020 and $900-1400 \mathrm{MtCO}_{2} \mathrm{e}$ by 2030 , based on FAIR/TIMER (lower end of the range) and CAT calculations (upper end of the range). This renewable energy target is in line with the Renewable Energy Roadmap 2030 (IRENA, 2014), according to which China could increase its share of renewable energy in the power sector from $20 \%$ to nearly $40 \%$ by 2030. These targets imply a substantive growth in wind, solar and hydropower. The renewable energy capacity projection by 2030 in the INDC scenario as calculated by the PECE model (Sha et al., 2015) is also similar.

\subsubsection{Transport; fuel efficiency improvements}

Private vehicle ownership has increased strongly in China over the last years, and this trend is expected to continue. Urban transport is currently one of the main causes of local air pollution in Chinese cities. A light commercial vehicle standard starting in 2015 is already in place and a standard of $20 \mathrm{~km} / 1$ by 2020 is currently under review (Braun et al., 2014). For the enhanced policy scenario, we assume that China can complement its already existing mitigation policies in transport with a fuel economy standard from today's level linearly towards a fuel economy standard of $47.5 \mathrm{~km} / \mathrm{l}$ for newly sold cars by 2035 , which is currently discussed in the EU for new cars in 2030. If this standard could be achieved by 2035, transport emissions would peak in 2025, despite of an increasing trend in activity. According to our analysis, this would decrease emissions by $1-54 \mathrm{MtCO}_{2} \mathrm{e}$ by 2020 and 7 to $50 \mathrm{MtCO}_{2} \mathrm{e}$ by 2030 , below the current policies development, based on FAIR/TIMER (lower end of the range) and CAT calculations (upper end of the range). 


\section{(a) $\mathrm{CO}_{2}$ emission for China}

energy- and industry related $\mathrm{CO}_{2}$ emissions $\left(\mathrm{Mt} \mathrm{CO}_{2}\right)$

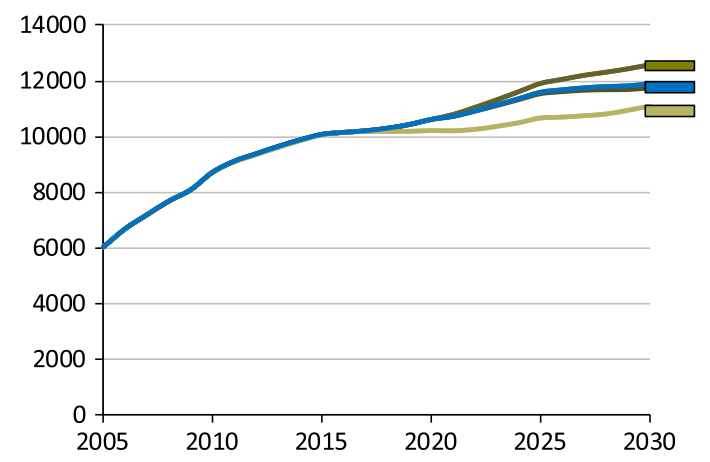

(c) Renewables share in primary energy

Percentage of total primary energy

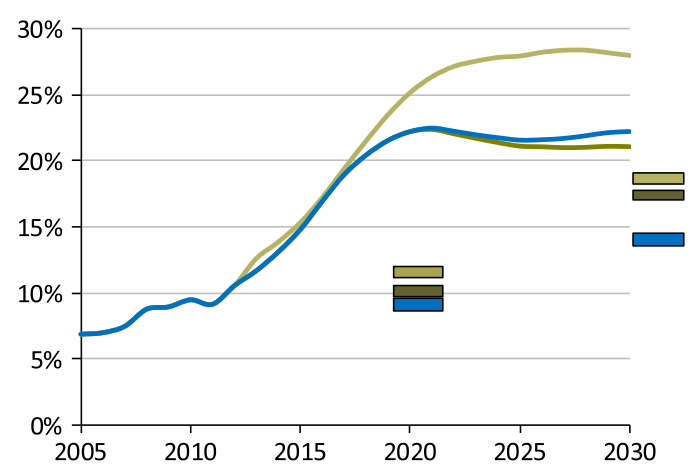

(b) $\mathrm{CO}_{2}$-intensity for China, relative to $\mathbf{2 0 0 5}$

$\mathrm{CO}_{2}$ emissions per GDP (\$2005), relative to 2005

$\begin{array}{llllll}2005 & 2010 \quad 2015 & 2020 & 2025 & 2030\end{array}$

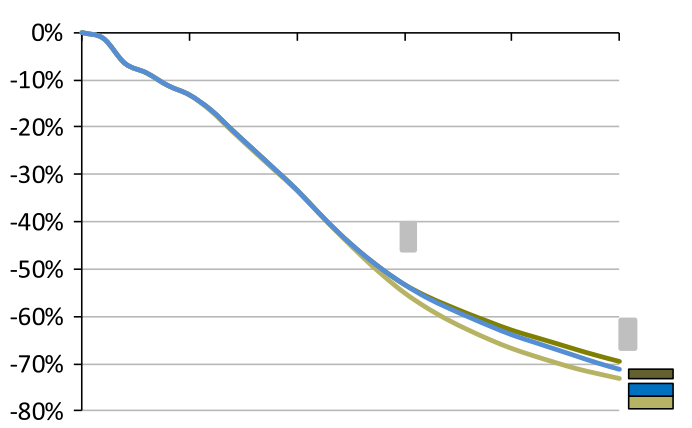

(d) Non-fossil share in primary energy

Percentage of total primary energy

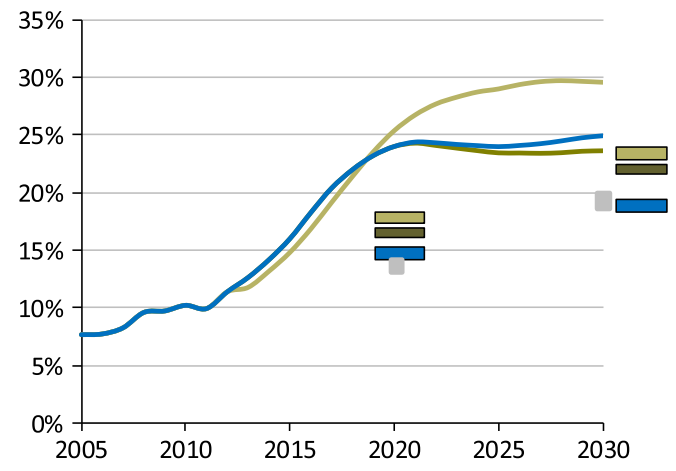

(e) Greenhouse gas emissions per capita for China Including $\mathrm{CO}_{2}$ emissions from land use

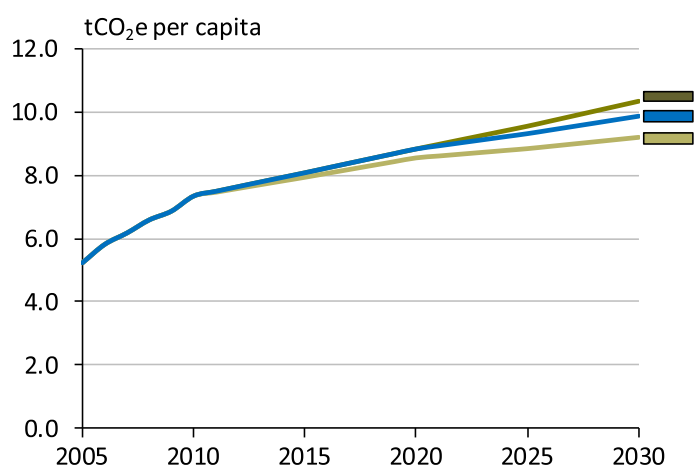

Current policies

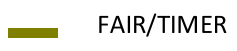

Bottom-up (only 2020 and 2030)

INDC scenario

FAIR/TIMER

Bottom-up (only 2020 and 2030)

Enhanced policies

FAIR/TIMER

$\square$ Bottom-up (only 2020 and 2030 )

INDC target

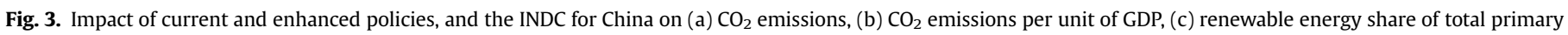

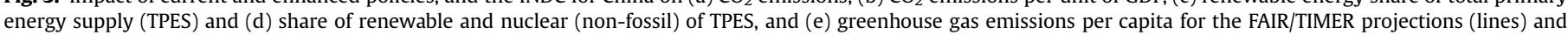

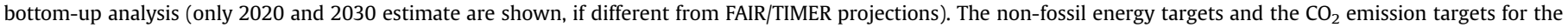
2020 pledge and the INDC targets are also included (grey squares).

\subsubsection{Buildings; efficiency improvements}

Residential and commercial floor space area is increasing strongly in China. In the CAT analysis, current building standards are replaced with a maximum primary energy demand of $50 \mathrm{kWh} /$ $\mathrm{m}^{2} / \mathrm{a}$ for new buildings, starting today. Based on a reference building in Shanghai, we estimate that current Chinese standards imply a primary energy demand of around $120 \mathrm{kWh} / \mathrm{m}^{2} / \mathrm{a}$. Additionally, we assume an autonomous efficiency improvement of $1 \%$ per year. In the FAIR/TIMER analysis, the effect of advanced heating and insulation measures was projected. This encompasses a gradual installation of advanced insulation in newly built houses between 2015 and 2030 and a 10\% improvement in the energy efficiency of water heating. The calculations show that efficiency improvements in buildings would lead to additional emission reductions of about $16-75 \mathrm{MtCO}_{2} \mathrm{e}$ by 2020 and $132-200 \mathrm{MtCO}_{2} \mathrm{e}$ by 2030, beyond those under current policies. The FAIR/TIMER estimates are at the lower end of the presented reduction ranges.

\subsubsection{HFC production and consumption}

A full implementation of the reduction scheme for the production and consumption of HFCs based on the 2014 North American Amendment Proposal (Appendix A.5) is assumed. For China, categorised as an Article 5 Party in the proposal, this would imply a $30 \%$ reduction in HFC consumption below the baseline by 
2025 and a 60\% reduction by 2031 (U.S. Environmental Protection Agency, 2014). The baseline for an Article 5 country is calculated as $100 \%$ of average HFC consumption and production and $40 \%$ of average HCFC consumption and production in 2011-2012. The FAIR/TIMER and CAT calculations show a reduction below the current policies scenario of about 0 to $185 \mathrm{MtCO}_{2} \mathrm{e}$ by 2020 and $150-460 \mathrm{MtCO}_{2}$ e by 2030.

\subsubsection{Forestry; the implementation and achievement of targets} concerning national forest cover for 2030

There are several nationwide programmes that support afforestation and plantation of forests. The National Forest Protection Programme (Barr and Cossalter, 2004; FAO, 2011) has stopped logging of natural forests at the upper reaches of the Yangtze and Yellow rivers; the China Fast-Growing and High-Yield Plantation Programme (Jiang and Zhang, 2003) has heavily supported pulpwood plantations; and the Grain for Green Programme (Deng et al., 2014; Dhiyoung, 2002; Liu and Wu, 2010) is supporting afforestation efforts by farmers. There is also a strong focus on the protection of wetlands, with a target of over $60 \%$ of the natural wetlands being protected by 2020 .

The various protection and plantation-supporting policies have been very effective in promoting afforestation, and China's forest cover has increased steadily during the last decade. In this scenario we assume that China would continue to promote afforestation efforts beyond the 2020 target as of China's Copenhagen pledge (UNFCCC, 2011). Assuming the same yearly level of afforestation effort after 2020, the policy would then aim to increase the forest coverage by an additional 27 million hectares as compared to the 2020 level. Based on current policies, the G4M model estimates that the forest cover would increase by 9 million hectares by 2030 , relative to the 2020 level. An additional 18 million hectares of afforestation would thus be required to reach the assumed target of 27 million hectares of afforestation. However, it is highly uncertain whether the additional 18 million hectares of land can be afforested through the introduction of additional policy measures. Based on G4M model calculations, it is estimated that only 0.2 million hectares of the additional 18 million hectares of afforestation can be fulfilled through the considered enhanced policy scenario, so the impact on reducing emissions is low. Furthermore, even though the total afforestation efforts are large, afforestation in China also raises environmental concerns following the vast deployment of exotic tree species and afforestation of naturally treeless areas, such as for the Tibetan highlands.

Summarising, the enhanced measures will have a moderate impact on emissions in 2020, but the effect in 2030 will be approximately $1.7 \mathrm{GtCO}_{2} \mathrm{e}$ according to the CAT analysis and $1.6 \mathrm{GtCO}_{2} \mathrm{e}$ according to the FAIR/TIMER analysis, both relative to the current policies scenario (for detailed results of the scenario, see Figs. 2 and 3). The reason that the reduction is lower in the FAIR/TIMER analysis is that FAIR/TIMER assumes lower emission projections under the current policies scenario. This is due to different renewable energy shares in the power sector after 2020 between FAIR/TIMER and CAT analysis. The CAT analysis is based on the WEO2014 Current Policies scenario, which shows a stabilisation trend in renewable energy. In the TIMER energy model calculations the renewable share increases due to the assumed ongoing investments in renewable energy after 2020, partly because of an increased rate of technology development resulting from the increased installed renewable capacity. Nevertheless, emission projections for the enhanced policy scenario of FAIR/ TIMER and CAT both lead to almost a stabilisation of emissions at 2020 emission levels in China, at about 13-14 $\mathrm{GtCO}_{2} \mathrm{e}$ (excluding LULUCF emissions). 
Table 5

Overview of domestic policies analysed in the enhanced policies scenario for China in addition to the current policies scenario.

\begin{tabular}{|c|c|c|}
\hline Sector & $\begin{array}{l}\text { Policy/ } \\
\text { measure }\end{array}$ & Target \\
\hline $\begin{array}{l}\text { Energy } \\
\text { supply }\end{array}$ & $\begin{array}{l}\text { Increased re- } \\
\text { newable en- } \\
\text { ergy supply }\end{array}$ & $\begin{array}{l}\text { Increase the share of renewable energy in electricity generation by } 1.35 \text { percentage points, per year, from } 2015 \text { onwards, up to about } 44 \% \text { by } \\
2030 \text {. This will lead to about } 1700 \mathrm{GW} \text { of renewable electricity by } 2030 \text { (compared to } 1400 \mathrm{GW} \text { (bottom-up) or } 1050 \mathrm{GW} \text { (FAIR/TIMER) by } \\
2030 \text { in the current policies scenario) }\end{array}$ \\
\hline Transport & $\begin{array}{l}\text { Fuel efficiency } \\
\text { in transport }\end{array}$ & $\begin{array}{l}\text { Achieve efficiency standards as currently discussed in the EU with a five-year delay ( } 34.4 \mathrm{~km} / \mathrm{l} \text { for new cars by } 2030 \text { and } 47.5 \mathrm{~km} / \mathrm{l} \text { by } 2035 \text { ) } \\
\text { (compared to } 20 \mathrm{~km} / \mathrm{l} \text { by } 2020 \text { in the current policies scenario) }\end{array}$ \\
\hline Buildings & $\begin{array}{l}\text { Building } \\
\text { efficiency }\end{array}$ & $\begin{array}{l}\text { Current building standards for primary energy demand for new buildings are replaced with highly efficient standard of } 50 \mathrm{kWh} / \mathrm{m}^{2} / \mathrm{a} \\
\text { (compared to baseline developments in the current policies scenario) }\end{array}$ \\
\hline HFCs & $\begin{array}{l}\text { Phase-down } \\
\text { of HFCs }\end{array}$ & $\begin{array}{l}\text { 30\% reduction in HFC consumption and production by } 2025 \text { and } 60 \% \text { by } 2031 \text { (compared to baseline developments with increasing emis- } \\
\text { sions in the current policies scenario) }\end{array}$ \\
\hline Forestry & $\begin{array}{l}\text { Continued af- } \\
\text { forestation ef- } \\
\text { forts after } \\
2020\end{array}$ & $\begin{array}{l}\text { Yearly afforestation from } 2020 \text { to 2030, as promoted earlier ( } 2.67 \text { Mha per year) (compared to baseline developments in the current policies } \\
\text { scenario) }\end{array}$ \\
\hline
\end{tabular}

\subsection{Emission levels consistent with Chinese INDC}

We also estimated the emission level resulting from full implementation of China's INDC, which includes the following four main elements: (i) the target to peak $\mathrm{CO}_{2}$ emissions no later than 2030, (ii) to increase the share of non-fossil fuels in the total primary energy supply to around $20 \%$ by 2030 (non-fossil energy target), (iii) to lower the carbon intensity of GDP by $60-65 \%$ below 2005 levels by 2030 , and (iv) to increase the forest stock volume by around 4.5 billion $\mathrm{m}^{3}$, compared to 2005 levels. China does not provide an absolute emissions level connected to these targets.

The INDC submission follows the earlier announcement, which only included the first two elements. According to the bottom-up calculations, ${ }^{7}$ the new carbon intensity target leads to a projected GHG emission level of 14.6-16.6 $\mathrm{GtCO}_{2} \mathrm{e}$ in 2030, including land use, which is above the emission level resulting from the current policies scenario. This is based on historic data from China's Statistical Yearbook and GDP projections from WEO2014 and IMF. Similar results are obtained by the FAIR/TIMER calculations, which projects emission levels ranging from 14.0 to $16.3 \mathrm{GtCO}_{2} \mathrm{e}$. These are based on the GDP projections in the OECD business-as-usual scenario (about 8.5\% GDP growth in the period 2010-2020, and 5\% in the period 2021-2030) and the IEA WEO 2014 (about 6.9\% GDP growth in the period $2010-2020$, and 5.3\% in the period 20212030), and using a variation of $\pm 1 \%$ GDP growth.

Potential emissions trajectories resulting from the first two elements of the INDC (related to the earlier announcement) have been quantified earlier by bottom-up analysis under the Climate Action Tracker (Climate Action Tracker Policy Brief, 2014). They considered two scenarios: 1 . peak emissions by 2030; and 2. peak emissions by 2025 , both in combination with the implemented non-fossil fuel target of $20 \%$. To quantify the emissions level resulting from the non-fossil energy target, the analysis took the World Energy Outlook 2014 current policies scenario as starting point, and added the effect of recently adopted policies, including the cap on coal, the target of at least $10 \%$ gas in total primary energy supply, and a share of $20 \%$ non-fossil fuels (excluding biomass). To illustrate potential peaking scenarios, we assumed that the growth rate of energy-related $\mathrm{CO}_{2}$ emissions linearly approaches zero between today and the respective year. For peaking in 2030 , the peaking scenario results in higher emissions than the emission level resulting from the non-fossil energy target, implying that the non-fossil energy target is sufficient for achieving a peak in 2030. A peak in 2025 (reflecting the provision of "with the

\footnotetext{
${ }^{7}$ The analysis of the Chinese INDC with this methodology was published by the same authors under the Climate Action Tracker: http://climateactiontracker. org/countries/china.html (accessed 2 September 2015).
}

intention to try to peak early") would require a $1 \mathrm{GtCO}_{2} \mathrm{e}$ reduction compared to the non-fossil energy target in 2030. If non- $\mathrm{CO}_{2}$ emissions from the reference scenario are added, total GHG emissions would still increase after 2030 . The projected emissions in 2030 are estimated at $13.6 \mathrm{GtCO}_{2} \mathrm{e}$. As the emission levels resulting from the carbon intensity target are higher, the projected GHG emission level of the INDC are dominated by the projected emission level resulting from the non-fossil target, as presented above. The detailed emission estimates for the energy-related $\mathrm{CO}_{2}$ emissions, the industry-related $\mathrm{CO}_{2}$ emissions and the other GHG emissions are given in Table 6.

The FAIR/TIMER calculations for the emissions peaking and non-fossil target use as starting point the GHG emission projections resulting from the current policies scenario, in which the share of $20 \%$ non-fossil fuels (excluding biomass) is also met, but the energy-related $\mathrm{CO}_{2}$ emissions show an increasing trend. To achieve the peaking of energy-related $\mathrm{CO}_{2}$ emissions before 2030, two carbon tax scenarios are developed that assume a linear increasing carbon tax starting in 2020, similar as in the IEA New Policies scenario. The resulting $\mathrm{CO}_{2}$ emission projections as calculated with the TIMER energy model peak by 2025 and 2030 in the two scenarios, a similar pattern for the GHG emission projections, as showed in Fig. 3 and Table 6. Similar as for the bottomup calculations, the projected emission levels of the INDC are the same, as the emission levels resulting from the carbon intensity target are higher.

For comparison reasons we have also analysed the energy-related $\mathrm{CO}_{2}$ emission projection of the INDC scenario of IEA (2015). This scenario shows an energy-related $\mathrm{CO}_{2}$ emission projection of $10.2 \mathrm{GtCO}_{2}$ in 2030 , which is similar as the lower estimate of the FAIR/TIMER calculations. It is also equal to the 2030 projection of the accelerated effort scenario of Zhang et al. (2014). We have also calculated the GHG emission projection for the IEA INDC scenario based on the following two adjustments: (a) For the industry-related $\mathrm{CO}_{2}$ emissions a similar trend of the energy-related $\mathrm{CO}_{2}$ emissions is used, using the EDGAR estimate as starting point. (b) For the non- $\mathrm{CO}_{2} \mathrm{GHG}$ emissions, the reference scenario of the EPA (US EPA, 2012) is used. The GHG emission projection for this adjusted scenario reaches about $13.8 \mathrm{GtCO}_{2} \mathrm{e}$ in 2030, which is within the range of the Bottom-up and FAIR/TIMER calculations.

The impact of increasing the Chinese forest stock volume by around 4.5 billion $\mathrm{m}^{3}$, as stated in the Chinese INDC, is estimated to only lead to minor reductions compared to the LULUCF $\mathrm{CO}_{2}$ emissions of the current policies scenario (as assumed in the estimates presented above). Current national policies is estimated with the G4M model to lead to an increase in the national forest carbon stock by roughly 1.2 billion $\mathrm{m}^{3}$ by 2020 , and 4.3 billion $\mathrm{m}^{3}$ by 2030 , both relative to the 2005 level. The majority of this 
Table 6

The energy-related $\mathrm{CO}_{2}$ emissions, the industry-related $\mathrm{CO}_{2}$ emissions and the other greenhouse gas emissions (including LULUCF) of the INDC for China for the bottom- up analysis and FAIR/TIMER calculations, and for the IEA New Policies scenario (adjusted).

\begin{tabular}{|c|c|c|c|c|}
\hline Scenario & 2012 & 2020 & 2025 & 2030 \\
\hline Bottom-up & $\mathrm{GtCO}_{2} \mathrm{e}$ & $\mathrm{GtCO}_{2} \mathrm{e}$ & $\mathrm{GtCO}_{2} \mathrm{e}$ & $\mathrm{GtCO}_{2} \mathrm{e}$ \\
\hline Energy-related $\mathrm{CO}_{2}$ emissions & 8.2 & {$[8.9 ; 9.3]$} & 9.4 & 10.6 \\
\hline $\begin{array}{l}\text { Industry-related } \mathrm{CO}_{2} \\
\text { emissions }\end{array}$ & 1.1 & 1.2 & 1.2 & 1.1 \\
\hline Non- $\mathrm{CO}_{2}$ GHG emissions & 1.7 & 2.1 & 2.6 & 3.1 \\
\hline LULUCF $\mathrm{CO}_{2}$ emissions & -0.4 & -0.3 & -0.3 & -0.3 \\
\hline $\begin{array}{l}\text { Total greenhouse gas } \\
\text { emissions }\end{array}$ & 10.7 & {$[12.3 ; 12.5]$} & 13.1 & 13.6 \\
\hline \multicolumn{5}{|l|}{ FAIR/TIMER } \\
\hline Energy-related $\mathrm{CO}_{2}$ emissions & 8.4 & 9.6 & {$[10.5 ; 10.5]$} & {$[10.3 ; 10.9]$} \\
\hline $\begin{array}{l}\text { Industry-related } \mathrm{CO}_{2} \\
\text { emissions }\end{array}$ & 1.0 & 1.0 & 1.1 & 1.0 \\
\hline Non- $\mathrm{CO}_{2}$ GHG emissions & 1.5 & 2.4 & 2.2 & 2.7 \\
\hline LULUCF $\mathrm{CO}_{2}$ emissions & -0.3 & -0.4 & -0.5 & -0.6 \\
\hline $\begin{array}{l}\text { Total greenhouse gas } \\
\text { emissions }\end{array}$ & 10.6 & 12.5 & {$[13.2 ; 13.3]$} & {$[13.5 ; 14.0]$} \\
\hline \multicolumn{5}{|l|}{$\begin{array}{l}\text { IEA New Policies scenario } \\
\text { (adjusted) }\end{array}$} \\
\hline Energy-related $\mathrm{CO}_{2}$ emissions & 8.2 & 9.5 & 9.9 & 10.2 \\
\hline $\begin{array}{l}\text { Industry-related } \mathrm{CO}_{2} \\
\text { emissions }\end{array}$ & 1.0 & 1.1 & 1.2 & 1.2 \\
\hline $\begin{array}{l}\text { Non- } \mathrm{CO}_{2} \text { GHG emissions } \\
\text { (EPA) }\end{array}$ & 1.630 & 1.9 & 2.2 & 2.6 \\
\hline LULUCF $\mathrm{CO}_{2}$ emissions & -0.3 & -0.2 & -0.2 & -0.2 \\
\hline $\begin{array}{l}\text { Total greenhouse gas } \\
\text { emissions }\end{array}$ & 10.4 & 12.1 & 13.0 & 13.8 \\
\hline
\end{tabular}

increase is related to the carbon accumulation in afforested land, and a carbon storage in existing forests due to that the projected harvest level for material and energy purposes is lower than the forest increment. However, the uncertainty of this estimate is high, and mainly related to the projection of the future harvest level and to how the target should be measured (above or below ground biomass, biomass expansion functions, and carbon content).

Summarising, setting aside the carbon intensity target, China's INDC's actions and non-fossil energy target lead to GHG emission levels of around 13.5-14.0 $\mathrm{GtCO}_{2} \mathrm{e}$ in 2030 and $\mathrm{CO}_{2}$ emission levels of around 11.3-11.8 $\mathrm{GtCO}_{2}$ (Table 6). Sha et al. (2015) show a similar estimate for the energy related $\mathrm{CO}_{2}$ emissions (including cement) of about $11.6 \mathrm{GtCO}_{2}$ in 2030 , but a more conservative estimate just under $13 \mathrm{Gt} \mathrm{GtCO}_{2}$ taking into account the energy statistics adjustment in 2014. Our GHG estimate is about the same as the range by Boyd et al. (2015) of 13.8-15.3 $\mathrm{GtCO}_{2} \mathrm{e}$ in 2030 .

\section{Caveats}

There are a number of caveats with the analysis. First of all, the study covers only the most effective national climate and energy policies and therefore does not provide a complete assessment of all policies. This could lead to underestimation of the total impact of all policy efforts to reduce emissions. Secondly, existing policies may change and new policies may be implemented. This implies that our assessment is explicitly limited to the current state of affairs. Third, the uncertainty ranges are based on only two methods or models. A broader selection of available model studies (including possible national studies) may result in a wider range of projected emission levels. Therefore, the uncertainty ranges in the results may be larger than the ranges given in this study. More insight into the uncertainty ranges could be obtained by using different models to perform these calculations. Fourth, the presented projections involve uncertainties, with the most important ones related to the uncertainty in historical emissions and GDP growth projections. Emission projections start from a base year based on historical data, and the estimated uncertainty could be as high as $15-20 \%$, as shown in this study. Fifth and finally, the selection of the enhancement measures is illustrative and not exhaustive. Therefore, this study does not give a quantitative assessment of the full climate and energy policy portfolio of possible enhancement measures, but it shows which policy measures could help to achieve China's INDC.

\section{Conclusions and policy implications}

National policies from China's 12th Five-Year Plan (FYP) and 12th FYP for Renewable Development are projected to lead to approximately the same emission levels as would be required to achieve the pledge for 2020 ( $13.5 \mathrm{GtCO}_{2} \mathrm{e}$, about 33\% above 2010 levels). The expected emission levels under current policies strongly depend on future economic growth and are projected to range between 14.7 and $15.4 \mathrm{GtCO}_{2}$ e by 2030 (including LULUCF), which is about $46-53 \%$ above the 2010 level.

The emission targets of China's pledge and its national policies are coupled to GDP, implying that the absolute emission target is very uncertain. For China, also the historical data can be uncertain. It is estimated that most international datasets have an uncertainty of the order of $10 \%$, but some estimated the uncertainty in the late 2000s as high as $15-20 \%$.

Under policy enhancement measures in the forestry, transport, buildings, and power sectors, and with reductions in hydrofluorocarbons, total emissions would keep increasing up to 2020 and subsequently would more or less stabilise at 2020 levels up to 2030 (13.1-13.7 $\mathrm{GtCO}_{2}$ e by 2030). The illustrative set of enhancement measures considered here have large potential for co-benefits, most importantly the improvement in local air quality. Air quality is a concern that China is aiming to tackle already, and policies such as efficiency standards for passenger vehicles and buildings, and limits to coal combustion support existing air pollution mitigation policies. The set of enhanced policies may therefore have a fair chance to be implemented in reality.

For its post 2020 contribution, China submitted its INDC on the 30th of June 2015, its main elements being (i) to peak $\mathrm{CO}_{2}$ emissions by 2030 or earlier, and ii) to achieve a share of $20 \%$ non-fossil energy in the total primary energy supply. We estimated that this requires a total $\mathrm{CO}_{2}$ emission level of $11.3-11.8 \mathrm{GtCO}_{2}$, equivalent to $30-40 \%$ above 2010 levels, with a corresponding total GHG emission level of 13.5-14 $\mathrm{GtCO}_{2}$ e by 2030 (35-40\% above 2010 levels). Therefore, current policies are likely not sufficient for achieving a peak in $\mathrm{CO}_{2}$ emissions in or before 2030, but enhanced GHG mitigation efforts could help to achieve this target.

\section{Acknowledgements}

The project was financed by the European Commission, Directorate General Climate Action, under contract to DG CLIMA (Service Contract no. 071303/2011/662342/SER/CLIMA.A4 - Renewal (Ares (2013)3407741)) renewed in November 2013. The project was also funded by the Dutch Ministry of Infrastructure and the Environment. We would also like to thank Pieter Boot (PBL) for comments.

\section{References}

Andres, R.J., Boden, T.A., Bréon, F.M., Ciais, P., Davis, S., Erickson, D., Gregg, J.S., Jacobson, A., Marland, G., Miller, J., Oda, T., Olivier, J.G.J., Raupach, M.R., Rayner, P. 
Treanton, K., 2012. A synthesis of carbon dioxide emissions from fossil-fuel combustion. Biogeosciences 9, 1845-1871.

Barr, C., Cossalter, C., 2004. China's development of a plantation-based wood pulp industry: government policies, financial incentives, and investment trends. Int. For. Rev. 6, 267-281.

Bloomberg New Energy Finance, 2013. The Future of China's Power Sector. 〈http:// about.bnef.com/white-papers/the-future-of-chinas-power-sector/ $\rangle$.

Boden, T.A., Marland, G., Andres, R.J., 2013. Global, regional, and national fossil-fuel $\mathrm{CO}_{2}$ emissions. Carbon Dioxide Information Analysis Center, Oak Ridge Nationa Laboratory, US Department of Energy, Oak Ridge, Tenn., U.S.Ahttp://dx.doi.org/ 10.3334/CDIAC/00001_V2013.

Boyd, R., Stern, N., Ward, B., 2015. What Will Global Annual Emissions of Greenhouse Gases be in 2030, and will They be Consistent with Avoiding Global Warming of More Than 2C?. ESRC Centre for Climate Change Economics and Policy and Grantham Research Institute on Climate Change and the Environment, London, p. 18.

Braun, N., Healy, S., Höhne, N., Schumacher, K., Hagemann, M., Duscha, V., Day, T., 2014. Instruments to increase climate policy ambition before 2020 - economic and political implications in selected industry and emerging countries. Ecofys, Öko Institut e.V, The Netherlands.

Cansino, J.M., Román, R., Rueda-Cantuche, J.M., 2015. Will China comply with its 2020 carbon intensity commitment? Environ. Sci. Policy 47, 108-117.

Chen, K., Reklev, S., 2014. China's National Carbon Market to Start in 2016 - Official. Reuters, Beijing.

Chen, W., Wu, Z., He, J., Gao, P., Xu, S., 2007. Carbon emission control strategies for China: a comparative study with partial and general equilibrium versions of the China MARKAL model. Energy 32, 59-72.

China National Energy Administration China National Renewable EC, 2012. China 12th Five-Year Plan for Renewable Energy Development (2011-2015).

Climate Action Tracker Policy Brief, 2014. China, US and EU post-2020 plans reduce projected warming. 〈http://climateactiontracker.org/assets/publications/brief ing_papers/CAT_Briefing_10122014.pdf).

Deng, L., Liu, G.B., Shangguan, Z.P., 2014. Land-use conversion and changing soil carbon stocks in China's 'Grain-for-Green' Program: a synthesis. Glob. Chang. Biol. 20, 3544-3556.

Dhiyoung, L., 2002. A Policy Review on Watershed Protection and Poverty Alleviation by the Grain for Green Programme in China. FAO.

Ecofys and Wuppertal Institute. Linking Mechanisms: Carbon Markets, Climate Finance and National Policies, 2014.

EIA, 2015. Total Carbon Dioxide Emissions from the Consumption of Energy. U.S. Energy Information Administration (EIA), United States.

den Elzen, M., Hof, A., van den Berg, M., Roelfsema, M., 2014. Climate policy. In: Stehfest, E., Van Vuuren, D., Kram, T., Bouwman, L. (Eds.), Integrated Assessment of Global Environmental Change with IMAGE 3.0-Model description and policy applications. PBL Netherlands Environmental Assessment Agency, The Hague, pp. 303-312.

den Elzen, M.G.J., Hof, A.F., Roelfsema, M., 2013. Analysing the greenhouse gas emission reductions of the mitigation action plans by non-Annex I countries by 2020. Energy Policy 56, 633-643.

European Environmental Agency, 2014. Trends and projections in Europe 2014, EEA (European Environment Agency), Copenhagen, Denmark.

FAO, 2011. Natural Forest Formations. FAO, China.

Fekete, H., Roelfsema, M., Höhne, N., den Elzen, M.G.J., Forsell, N., Becerra, S., 2015 The impact of good practice policies on regional and global greenhouse gas emissions. NewClimate Institute, PBL Netherlands Environmental Assessment Agency and the International Institute for Applied Systems Analysis, Cologne, Germany. 〈http://newclimate.org/2015/07/29/the-impact-of-good-practice-po licies-on-regional-and-global-greenhouse-gas-emissions/ $\rangle$.

Fekete, H., Vieweg, M., Mersmann, F., 2013a. Climate Change Mitigation in Emerging Economies: From Potentials to Action. Dessau, Germany.

Fekete, H., Vieweg, M., Rocha, M., Braun, N., Lindberg, M., Gütschow, J., Jefferey, L., Höhne, N., Hare, B., Schaeffer, M., Macey, K., Larkin, J., 2013b. Analysis of Current Greenhouse Gas Emission Trends. Climate Action Tracker. Climate Analytics, Ecofys and the Potsdam Institute for Climate Impact Research (PIK).

Government of China, China, 1994. The People's Republic of China initial national communication on climate change. State Development Planning Commission. 〈http://unfccc.int/resource/docs/natc/chnnc1e.pdf).

Government of China, 2012. The second national communication on climate change of the People's Republic of China. National Development and Reform Commission. 〈http://unfccc.int/resource/docs/natc/chnnc2e.pdf〉.

Government of China, 2013. Air Pollution Control Action Plan. State Council, Beijing.

Grantham Institute for Climate Change, 2010. Achievement of international near term targets for $\mathrm{CO}_{2}$ emissions mitigation. 〈http://www.metoffice.gov.uk/med ia/pdf/n/1/AVOID WS2_D1_16 China_and_India_V2.pdf).

Gregg, J.S., Andres, R.J., Marland, G., 2008. China: Emissions pattern of the world leader in $\mathrm{CO}_{2}$ emissions from fossil fuel consumption and cement production. Geophysical Research Letters 35, L08806.

Guan, D., Liu, Z., Geng, Y., Lindner, S., Hubacek, K., 2012. The gigatonne gap in China's carbon dioxide inventories. Nat. Clim. Chang. 2, 672-675.

Gusti, M., 2010. An algorithm for simulation of forest management decisions in the global forest model. Artif. Intell. N4, 45-49.

Gusti, M., Kindermann, G., 2011. An Approach to Modeling Landuse Change and Forest Management on a Global Scale. In: Kacprzyk, J., Pina, N., Filipe, J. (Eds.), SciTePress-Science and Technology Publications, Portugal, pp. 180-185.

Havlík, P., Valin, H., Herrero, M., Obersteiner, M., Schmid, E., Rufino, M.C., Mosnier, A., Thornton, P.K., Böttcher, H., Conant, R.T., Frank, S., Fritz, S., Fuss, S., Kraxner,
F., Notenbaert, A., 2014. Climate change mitigation through livestock system transitions. Proc. Natl. Acad. Sci. U.S.A. 111, 3709-3714.

ICCT, 2014. Where we work: China.

IEA, 2013a. Energy Statistics and Energy Balances. IEA, Paris.

IEA, 2013b. World Energy Outlook 2013. International Energy Agency, Paris, France.

IEA, 2014. World Energy Outlook 2014. International Energy Agency, Paris, France.

IEA, 2015. Energy and Climate Change, World Energy Outlook Special Report. International Energy Agency. 〈https://www.iea.org/publications/freepublications/ publication/WEO2015SpecialReportonEnergyandClimateChange.pdf $\rangle$, Paris, France.

IRENA, 2014. Renewable Energy Prospects: China, REmap 2030 Analysis. IRENA, Abu Dhabi.

Jiang, K., Zhuang, X., Miao, R., He, C., 2013. China's role in attaining the global $2{ }^{\circ} \mathrm{C}$ target. Clim. Policy 13, 55-69.

Jiang, Z., Zhang, S.Y., 2003. China's plantation forests for sustainable wood supply and development. XII World Forestry Congress, 2003, Québec City, Canada.

Johansson, D.J.A., Lucas, P.L., Weitzel, M., Ahlgren, E.O., Bazaz, A.B., Chen, W., den Elzen, M.G.J., Ghosh, J., Grahn, M., Liang, Q.M., Peterson, S., Pradhan, B.K., van Ruijven, B.J., Shukla, P.R., van Vuuren, D.P., Wei, Y.M., 2014. Multi-model comparison of the economic and energy implications for China and India in an international climate regime. Mitig. Adapt. Strat. Glob. Chang., 1-25.

JRC/PBL, 2012. EDGAR version 4.2 FT2010. Joint Research Centre of the European Commission/PBL Netherlands Environmental Assessment Agency. 〈http://edgar. jrc.ec.europa.eu/index.php $\rangle$.

Liu, C., Wu, B., 2010. 'Grain for Green programme' in China: Policy making and implementation?. The University of Nottingham, China Policy Institute, Nottingham.

Liu, Z., Guan, D., Wei, W., Davis, S.J., Ciais, P., Bai, J., Peng, S., Zhang, Q., Hubacek, K., Marland, G., Andres, R.J., Crawford-Brown, D., Lin, J., Zhao, H., Hong, C., Boden, T. A., Feng, K., Peters, G.P., Xi, F., Liu, J., Li, Y., Zhao, Y., Zeng, N., He, K., 2015, Reduced carbon emission estimates from fossil fuel combustion and cement production in China. Nature 524, 335-338.

Nachmany, M., Fankhauser, S., Townshend, T., Collins, M., Landesman, T., Matthews, A., Pavese, C., Rietig, K., Schleifer, P., Setzer, J., 2014. The GLOBE Climate Legislation Study: A Review of Climate Change Legislation in 66 Countries, London: GLOBE International and the Grantham Research Institute, Fourth Edition London School of Economics.

National Development Reform Commission, 2007. Medium and Long Term Development Plan for Renewable Energy in China.

NBSC, 2015. Statistical Communiqué of the People's Republic of China on the 2014 National Economic and Social Development. 〈http://www.stats.gov.cn/english/ PressRelease/201502/t20150228_687439.html〉.

OECD, 2012. OECD Environmental Outlook to 2050. OECD, Paris.

Olivier, J.G.J., Janssens-Maenhout, G., Muntean, M., Peters, J.A.H.W., 2015. Trends in Global $\mathrm{CO}_{2}$ Emissions: 2015 Report. PBL Netherlands Environmental Assessment Agency, Bilthoven, the Netherlands.

Olivier, J.G.J., Janssens-Maenhout, G., Muntean, M., Peters, J.A.H.W., 2014. Trends in global $\mathrm{CO}_{2}$ emissions; 2014 Report. The Hague: PBL Netherlands Environmental Assessment Agency; Ispra: European Commission, Joint Research Centre: 〈www.pbl.nl/en or www.edgar.jrc.ec.europa.eu〉.

Richerzhagen, C., Tv, Frieling, Hansen, N., Minnaert, A., Netzer, N., Rußbild, J., 2008. Energy Efficiency in Buildings in China: Policies, Barriers and Opportunities. German Development Institute, Bonn.

Sha, F., Ji, Z., Linwei, L., 2015. An Analysis of China's INDC. China National Center for Climate Change Strategy and International Cooperation, Beijing, China, p. 12.

Sun, G., 2010. Coal in China: resources, uses, and advanced coal technologies. In: Pew Center on Global Climate Change (Ed.), Coal Initiative Reports - White Paper Series. Pew Center on Global Climate Change, Arlington, VA.

Tavoni, M., Kriegler, E., Riahi, K., van Vuuren, D.P., Aboumahboub, T., Bowen, A., Calvin, K., Campiglio, E., Kober, T., Jewell, J., Luderer, G., Marangoni, G., McCollum, D., van Sluisveld, M., Zimmer, A., van der Zwaan, B., 2015. Post-2020 climate agreements in the major economies assessed in the light of global models. Nat. Clim. Chang. 5, 119-126.

The People's Republic of China, 2011. China's 12th Five Year Plan (Twelfth Five-Year Guideline, 2011-2015). 〈http://www.gov.cn/2011lh/content_1825838.htm〉.

The People's Republic of China, 2012. China 12th Five-Year Plan for Renewable Energy Development (2011-2015).

The People's Republic of China, 2014a. Energy Development Strategy Action Plan (2014-2020). 〈http://www.gov.cn/zhengce/content/2014-11/19/content_9222. htm>.

The People's Republic of China, 2014b. National Action Plan on Climate Change (2014-2020). 〈http://www.sdpc.gov.cn/gzdt/201411/ W020141104591413713551.pdf〉.

Townshend, T., Fankhauser, S., Matthews, A., 2011. The GLOBE Climate Legislation Study, Continued progress on mandates, but the emission challenge remains. Globe International, World Summit of Legislators. London School of Economics and Political Science, United Kingdom.

U.S. Environmental Protection Agency, 2014. Summary: North American 2014 HFC Submission to the Montreal Protocol. U.S. Environmental Protection Agency, 〈http://www.epa.gov/ozone/intpol/mpagreement.html〉.

UNEP, 2014. The Emissions Gap Report 2014: A UNEP Synthesis Report. United Nations Environment Programme (UNEP), Nairobi.

UNFCCC, 2011. Compilation of information on nationally appropriate mitigation actions to be implemented by Parties not included in Annex I to the Convention. FCCC/AWGLCA/2011/INF.1. 〈http://unfccc.int/resource/docs/2011/awgl ca14/eng/inf01.pdf $\rangle$. 
US EPA, 2012. Global Anthropogenic Non-CO2 Greenhouse Gas Emissions: 19902030: Revised Version 2012

Van Vuuren, D., Van Ruijven, B., Girod, B., Daioglou, V., Edelenbosch, O., Deetman, S., 2014. Energy supply and demand. In: Stehfest, E., Van Vuuren, D., Kram, T., Bouwman, L. (Eds.), Integrated Assessment of Global Environmental Change with IMAGE 3.0-Model Description and Policy Applications. PBL Netherlands Environmental Assessment Agency, The Hague, pp. 71-152.

White House, 2014. U.S.-China Joint Announcement on Climate Change. Beijing, China, availaible at: 〈http://www.whitehouse.gov/the-press-office/2014/11/11/ us-china-joint-announcement-climate-change $\rangle$.

World Bank, 2007. Cost of Pollution in China: Economic Estimates of Physical Damages.
World Bank and Climate Works Foundation, 2014. Climate-Smart Development: Adding up the Benefits of Actions that Help Build Prosperity, End Poverty and Combat Climate Change.

Yang. Y., Zhang, J., Wang, C., 2014. Is China on Track to Comply with Its 2020 Copenhagen Carbon Intensity Commitment? p. 40.

Zhang, X., Karplus, V.J., Qi, T., Zhang, D., He, J., 2014. Carbon Emissions in China: How Far Can New Efforts Bend the Curve?. Massachusetts Institute of Technology, Cambridge, MA.

Zhou, N., Levine, M.D., Price, L., 2010. Overview of current energy-efficiency policies in China. Energy Policy 38, 6439-6452.

Zhu, S.L., 2014. Comparison and analysis of $\mathrm{CO}_{2}$ emissions data for china. Adv. Clim. Chang. Res. 5, 17-27. 